\title{
Modelling the impact of Siboglinids on the biogeochemistry of the Captain Arutyunov mud volcano (Gulf of Cadiz)
}

\author{
K. Soetaert ${ }^{1}$, D. van Oevelen ${ }^{1}$, and S. Sommer ${ }^{2}$ \\ ${ }^{1}$ Royal Netherlands Institute for Sea Research, Yerseke, the Netherlands \\ ${ }^{2}$ GEOMAR Helmholtz-Zentrum für Ozeanforschung, Kiel, Germany
}

Correspondence to: K. Soetaert (karline.soetaert@nioz.nl)

Received: 11 May 2012 - Published in Biogeosciences Discuss.: 7 June 2012

Revised: 26 November 2012 - Accepted: 30 November 2012 - Published: 21 December 2012

\begin{abstract}
A 2-Dimensional mathematical reaction-transport model was developed to study the impact of the muddwelling frenulate tubeworm Siboglinum sp. on the biogeochemistry of a sediment (MUC15) at the Captain Arutyunov mud volcano (CAMV). By explicitly describing the worm in its surrounding sediment, we are able to make budgets of processes occurring in- or outside of the worm, and to quantify how different worm densities and biomasses affect the anaerobic oxidation of methane (AOM) and sulfide reoxidation (HSox).
\end{abstract}

The model shows that, at the observed densities, the presence of a thin worm body is sufficient to keep the upper $10 \mathrm{~cm}$ of sediment well homogenised with respect to dissolved substances, in agreement with observations. By this "bio-ventilation" activity, the worm pushes the sulfatemethane transition (SMT) zone downward to the posterior end of its body, and simultaneously physically separates the sulfide produced during the anaerobic oxidation of methane from oxygen. While there is little scope for AOM to take place in the tubeworm's body, $70 \%$ of the sulfide that is produced by sulfate reduction processes or that is advected in the sediment is preferentially shunted via the organism where it is oxidised by endosymbionts providing the energy for the worm's growth. The process of sulfide reoxidation, occurring predominantly in the worm's body is thus very distinct from the anaerobic oxidation of methane, which is a diffuse process that takes place in the sediments in the methane-sulfate transition zone. We show how the sulfide oxidation process is affected by increasing densities and length of the frenulates, and by upward advection velocity.

Our biogeochemical model is one of the first to describe tubeworms explicitly. It can be used to directly link biological and biogeochemical observations at seep sites, and to study the impacts of mud-dwelling frenulates on the sediment biogeochemistry under varying environmental conditions. Also, it provides a tool to explore the competition between bacteria and fauna for available energy resources.

\section{Introduction}

A significant amount $\left(75-320 \mathrm{Tg} \mathrm{yr}^{-1}\right)$ of methane, a potent greenhouse gas, is released from marine sediments overlying gas hydrates or experiencing high organic matter deposition (Valentine, 2002). However, only a small fraction (5$20 \mathrm{Tg} \mathrm{yr}^{-1}$ ) of the methane that seeps into the ocean floor from the deep biosphere is eventually released to the atmosphere. This is because most of the methane moving upwards in sediments is oxidised by microbes that transform the methane into microbial biomass and carbon dioxide.

The anaerobic oxidation of methane (AOM), which uses sulfate as an electron acceptor, constitutes a major sink for methane (Reeburgh, 1996). AOM couples the sulfate reduction to methane oxidation by the following net chemical reaction (Reeburgh, 1996):

$\mathrm{CH}_{4}+\mathrm{SO}_{4}^{2-} \rightarrow \mathrm{HCO}_{3}^{-}+\mathrm{HS}^{-}+\mathrm{H}_{2} \mathrm{O}$

AOM takes place in a relatively narrow region of the sediment, the sulfate-methane transition (SMT) zone, and is a very effective barrier to methane release from marine sediments (Boetius and Suess, 2004; Kruger et al., 2005). $\mathrm{AOM}$ is performed by a consortium of free-living sulfatereducing bacteria and methane-oxidizing Archaea (Boetius et al., 2000) that use the catabolic energy of the reaction for their metabolism and growth. 
One of the byproducts of AOM is sulfide, a reduced compound that contains enough energy for other types of bacteria to grow on. Many thioautotrophic bacteria use oxygen as an electron acceptor but some bacteria, such as Beggiatoa can use intracellularly stored nitrate for sulfide oxidation (Jørgensen and Nelson, 2004; Cardoso et al., 2006).

In sediments where sulfide and oxygen co-occur in a narrow region close to the sediment-water interface, free-living bacteria such as Beggiatoa which may form the typical white mats (de Beer et al., 2006) can perform the reoxidation of sulfide. Some free-living thiotrophic bacteria are adapted to bridge gaps between the supply of oxygen and sulfide for example by vertical migration or electron shuttling (Nielsen et al., 2010). However, when sulfide and oxygen are physically separated over decimetres, another strategy is the symbiosis with an animal host such as Siboglinid tubeworms and clams (Sibuet and Olu, 1998). These organisms provide the thioautotrophic bacteria access to oxygen and sulfide, necessary for the generation of energy and bacterial biomass, and in return a fraction of the carbon fixed by the symbiont is used for the host's metabolism and biosynthesis (Cavanaugh et al., 2006).

Cold seeps and mud volcanoes are methane- and sulfiderich sediment ecosystems with normal temperatures and are found all around continental margins (Sibuet and Olu, 1998; Levin, 2005; Judd and Hovland, 2007). In these systems the oxidation of methane provides one source of carbon and energy, with another energy source provided by the high sulfide concentrations that are used by sulfide-oxidising bacteria (Levin, 2005).

The cold seep mud volcano Captain Arutyunov is situated in the Gulf of Cadiz, a tectonically active area of the European continental margin, at a depth of $1200 \mathrm{~m}$ (Niemann et al., 2006). It has a characteristic cone shape that is approximately $1000 \mathrm{~m}$ across and $100 \mathrm{~m}$ high. Its environments form a mosaic of bare sediments that are covered with clay stones ("clasts") and sediments inhabited by chemosynthetic communities. This mud volcano has been studied intensively and porewater profiles are available from various habitats (Niemann et al., 2006; Hensen et al., 2007; Sommer et al., 2009).

Amongst the enigmatic creatures that live in the methanerich sediments of the Captain Arutyunov mud volcano (CAMV) are the small mud-dwelling frenulate tubeworms, many of which belong to the genus Siboglinum (Hilario et al., 2010; Sommer et al., 2009). These animals that lack a digestive tract, predominantly rely on endosymbiotic sulfideoxidising bacteria for their nourishment. Barely as thick as a human hair, they are present in very high densities at CAMV and extend some $10 \mathrm{~cm}$ deep in the sediment (Sommer et al., 2009).

The biogeochemistry of cold seeps has been addressed in several observational (e.g., Niemann et al., 2006) and modelling studies (e.g., Martens and Berner, 1977; Luff et al., 2004; Wallmann et al., 1997; Haese et al., 2003; Fischer et al., 2012). However, most modelling studies focus on the
AOM process (reviewed in Regnier et al., 2011), and the fate of sulfide has received much less attention. In addition, the bio-ventilation activity of seep fauna on sediment biogeochemistry is usually represented by an approximate description that averages the worm with the surrounding sediment (Aller, 1980) without explicitly describing the animals (but see Cordes et al., 2005).

In this manuscript we model the effects of the muddwelling frenulate Siboglinum sp. on the biogeochemistry of a sediment (referred to as MUC15 in Sommer et al., 2009) of the Captain Arutyunov mud volcano. The 2-D multicomponent reaction-transport model describes the processes affecting oxygen, methane, sulfate and sulfide in a tiny, wellmixed cylinder, which represents the worms body and tube. The worm is surrounded by an annulus of sediment, where transport is dominated by seepage from below and molecular diffusion. To account for the cylindrical shape of the worm, the reaction-diffusion-advection equations are represented in a cylindrical coordinate system. We first describe the sediment biogeochemistry, then make a tentative budget that distinguishes between the worm and its surrounding sediment, and finally explore impacts of different seepage rates and worm densities and lengths on the biogeochemistry of the CAMV. Our aim is to quantify the effects of animal activity on the biogeochemistry of cold seep sediments and its contribution to the biogeochemical processes of this environment.

\section{Material and methods}

\subsection{Study site}

The mud volcano Captain Arutyunov is situated in the Gulf of Cadiz (Fig. 1). We model the sediment described as MUC15 ( $\left.35^{\circ} 39.696^{\prime} \mathrm{N}, 07^{\circ} 20.013^{\prime} \mathrm{W}\right)$, sampled on 12 May 2006, at $1322 \mathrm{~m}$ depth (Sommer et al., 2009). Methodological details on sampling and analysis are available in Sommer et al. (2009). Briefly, the sediment was sampled using benthic observatories and a TV guided multiple corer (MUC), while in situ flux measurements were conducted using the Biogeochemical Observatory (BIGO) and the Fluid Flux Observatory (FLUFO) as described in detail by Sommer et al. (2008). After in situ measurements, the incubated sediments were retrieved for amongst other on board pore water analyses of methane, hydrogen sulfide, oxygen, sulfate and porosity.

\subsection{Modelling}

The main aim of our study was to investigate to what extent the activity of the small tubeworm Siboglinum sp., the dominant inhabitant of the system, is able to modify the biogeochemical conditions of the surrounding sediment. In sediments inhabited by these worms and similar organisms, one often finds profiles that exhibit a rather uniform 


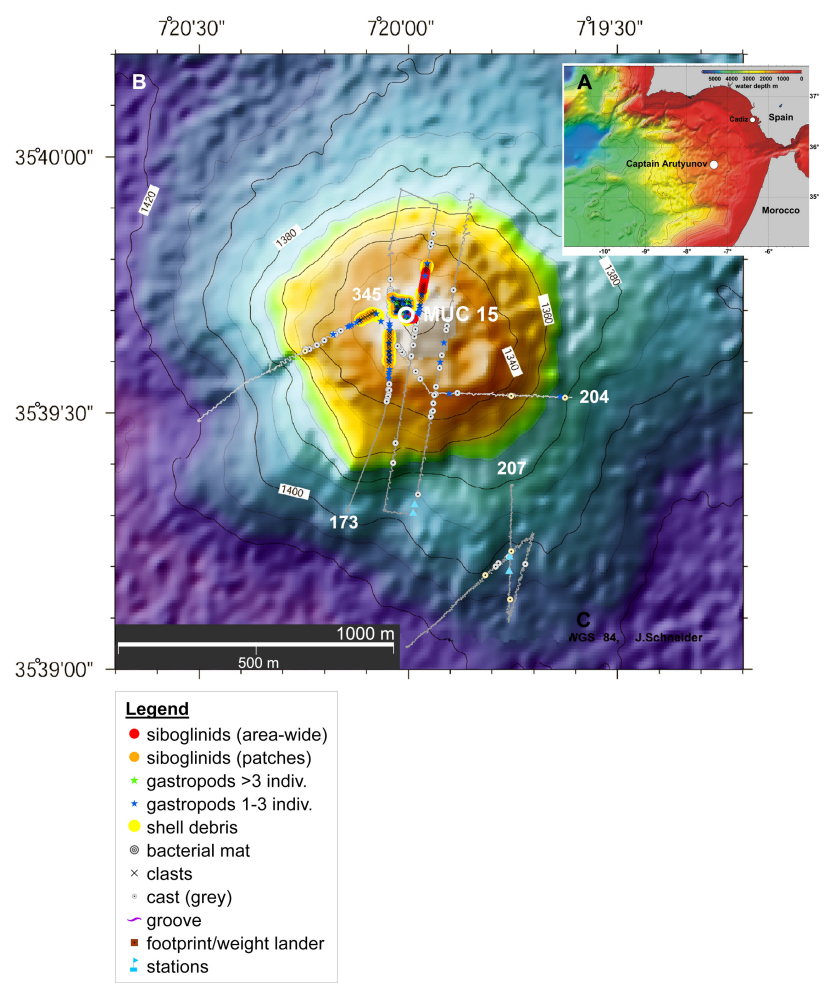

Fig. 1. (A) Location of the mud volcano Captain Arutyunov in the Gulf of Cadiz. (B) Bathymetric map of the Captain Arutyunov mud volcano with indications of major distribution patterns of fauna and lithogenic features. (C) Methane concentrations measured $5 \mathrm{~m}$ above the sea floor.

concentration of sulfate overlying a zone of rapid change, the SMT zone. The uniform concentration in the upper zone is generally attributed to the bio-ventilating activity of animals living in these sediments. In modelling the AOM process, some authors dealt with this by imposing the upper boundary of the AOM zone at the bottom of this bio-irrigated zone (e.g. Haese et al., 2003). Other authors use a nonlocal exchange formulation where the concentration difference between the overlying water and the average porewater concentration drives the exchanges (Regnier et al., 2011). Whereas there are many cases in which such parameterised description of animal bio-irrigation activity are valid (reviewed in Grigg et al., 2005), it is neither straightforward, using this formalism, to estimate the effects of animal density on biogeochemistry, nor does this allow to elucidate the direct contribution of the worm to the different biogeochemical processes.

Rather than using the sediment-averaged description, we therefore described the biogeochemical conditions inside the cylindrical body of the worm in an explicit way. This is achieved by implementing the biogeochemical model in a 2Dimensional grid, using a cylindrical coordinate system. The sediment is then mentally divided in equally-sized cylinders, each with a "worm" in the centre, that are closely packed (Fig. 2a).

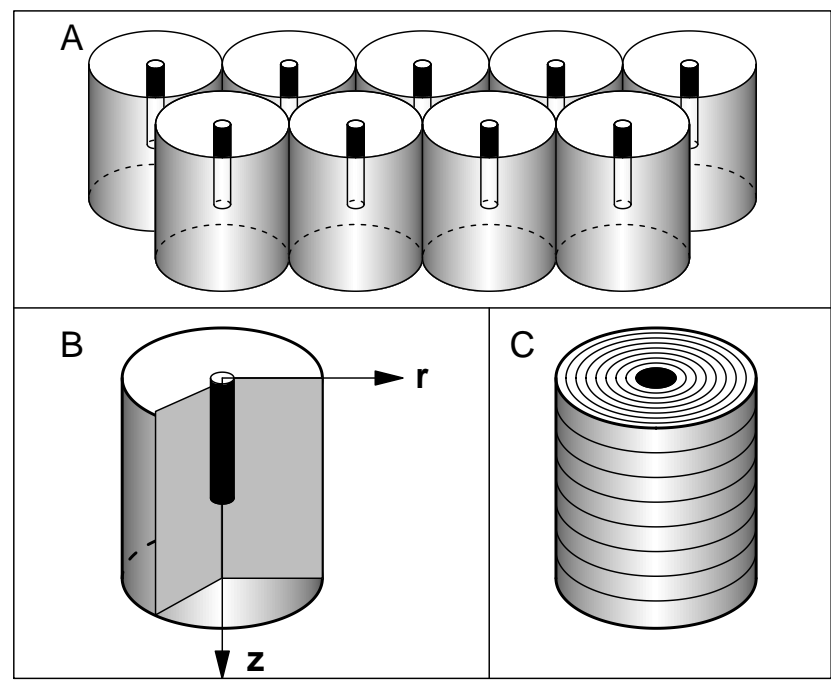

Fig. 2. (A) Schematic representation of the sediment, consisting of a set of cylindrical tubes, with the worm in the centre (black). (B) Only one cylinder is modeled in a 2-D setting, along a radial axis $(r)$ and a depth axis $(z)$. (C) The numerical discretisation subdivides the cylinder in a stack of annuluses.

The model equations (see below) apply to one cylinder, in a two-coordinate $(r, z)$ system (Fig. $2 b$ ). For our application the sediment cylinder is of length $L=35 \mathrm{~cm}$ (in the $\mathrm{z}$-direction), the depth of the sampled sediment core. We assumed a worm density equal to 17500 individuals per $\mathrm{m}^{2}$, as observed in station MUC15 (Sommer et al., 2009). This implies that a worm exerts its influence over a surface area of $1 \times 10^{4} / 17500=0.58 \mathrm{~cm}^{2}$. Consequently, the radius of the cylinder, $R$, is equal to $0.43 \mathrm{~cm}$ (Table 1 ). The worm itself, $11 \mathrm{~cm}$ long $(\mathrm{Lw})$, and $100 \mu \mathrm{m}$ thick $(2 \cdot \mathrm{Rw})$, is positioned in the centre of the cylinder and near the sediment-water interface (Fig. 2). The implicit assumption in modelling a 3Dimensional environment in a 2-D cylindrical coordinate system is that the solute concentrations do not change along the cylindrical slices.

The biogeochemical processes are described using the same formulations in- and outside of the worm. The only feature that distinguishes the worm from its surrounding sediment is that fluids in the worm (and its tube) are mixed at a high rate while molecular diffusion prevails in the surrounding sediment (Table 1). In addition, because $\mathrm{Si}$ boglinum species are known to absorb organic compounds through their thin tubes (Little and Gupta, 1969; Southward et al., 1979), we assumed that the permeability of the worm's body-wall and tube is the same as the surrounding sediments. Diffusion of water and solutes through the tube wall in both directions has indeed been demonstrated experimentally (Southward and Southward, 1963).

The diagenetic model considers the reactive chemical species methane $\left(\mathrm{CH}_{4}\right)$, sulfate $\left(\mathrm{SO}_{4}^{2-}\right)$, sulfide $\left(\mathrm{HS}^{-}\right)$ and oxygen $\left(\mathrm{O}_{2}\right)$. The 2-D mass-conservation equation 
Table 1. Parameters and driving variables in the model. Last column represents the normalised sensitivity of the integrated AOM rate on each parameter, estimated as AOM sens $=\frac{\text { par }}{\mathrm{AOM}(\mathrm{ref})} \frac{\partial \mathrm{AOM}}{\partial \mathrm{par}} \cdot * *: 0.01-0.1 ; *: 0.001-0.01 ;-:<0.001$.

\begin{tabular}{|c|c|c|c|c|}
\hline Parameter & Description & Value & Units & AOM sens \\
\hline$T$ & Bottom water temperature & 4 & ${ }^{\circ} \mathrm{C}$ & - \\
\hline$L$ & Depth of modeled sediment & 35 & $\mathrm{~cm}$ & $*$ \\
\hline$R$ & Total modeled radius & 0.43 & $\mathrm{~cm}$ & - \\
\hline Lw & Length of worm & 11 & $\mathrm{~cm}$ & - \\
\hline Rw & Radius of the worm & 0.005 & $\mathrm{~cm}$ & - \\
\hline$\phi$ & Porosity & 0.6 & - & $* *$ \\
\hline$u$ & Upwelling velocity & $-20 / 365$ & $\mathrm{~cm} \mathrm{~d}^{-1}$ & * \\
\hline $\mathrm{Ds}_{\mathrm{O}_{2}}$ & Sediment diffusion coeff. & 0.61 & $\mathrm{~cm}^{2} \mathrm{~d}^{-1}$ & - \\
\hline $\mathrm{Ds}_{\mathrm{H}_{2} \mathrm{~S}}$ & Sediment diffusion coeff. & 0.43 & $\mathrm{~cm}^{2} \mathrm{~d}^{-1}$ & - \\
\hline $\mathrm{Ds}_{\mathrm{CH}_{4}}$ & Sediment diffusion coeff. & 0.46 & $\mathrm{~cm}^{2} \mathrm{~d}^{-1}$ & $*$ \\
\hline $\mathrm{Ds}_{\mathrm{HSO}_{4}^{-}}$ & Sediment diffusion coeff. & 0.32 & $\mathrm{~cm}^{2} \mathrm{~d}^{-1}$ & $*$ \\
\hline$D_{\mathrm{w}}$ & Worm mixing coeff. & $1 \mathrm{e}^{5}$ & $\mathrm{~cm}^{2} \mathrm{~d}^{-1}$ & - \\
\hline$\left.\mathrm{O}_{2}\right|_{z=0}$ & Bottom water oxygen conc. & 219 & $\mu \mathrm{mol} \mathrm{L}-1$ & - \\
\hline$\left.\mathrm{O}_{2}\right|_{z=L}$ & Deep oxygen conc. & 0 & $\mu \mathrm{mol} \mathrm{L}-1$ & - \\
\hline$\left.\mathrm{SO}_{4}\right|_{z=0}$ & Bottom water sulfate conc. & 29685 & $\mu \mathrm{mol} \mathrm{L}-1$ & * \\
\hline$\left.\mathrm{SO}_{4}\right|_{z=\mathrm{L}}$ & Deep sulfate conc. & 0 & $\mu \mathrm{mol} \mathrm{L}-1$ & - \\
\hline$\left.\mathrm{HS}\right|_{z=0}$ & Bottom water sulfide conc. & 0 & $\mu \mathrm{mol} \mathrm{L}-1$ & - \\
\hline$\left.\mathrm{HS}\right|_{z=\mathrm{L}}$ & Deep sulfide conc. & 4000 & $\mu \mathrm{mol} \mathrm{L}-1$ & - \\
\hline$\left.\mathrm{CH}_{4}\right|_{z=0}$ & Bottom water methane conc. & 2.1 & $\mu \mathrm{mol} \mathrm{L}^{-1}$ & - \\
\hline$\left.\mathrm{CH}_{4}\right|_{z=\mathrm{L}}$ & Deep methane conc. & 9500 & $\mu \mathrm{mol} \mathrm{L}-1$ & $*$ \\
\hline$k_{\mathrm{AOM}}$ & Rate of AOM & $1.37 \times 10^{-5}$ & $(\mu \mathrm{mol} \mathrm{L}-1)^{-1} \mathrm{~d}^{-1}$ & - \\
\hline$k_{\mathrm{rHSox}}$ & Rate of HS oxidation & 5000 & $\left(\mu \mathrm{mol} \mathrm{L}{ }^{-1}\right)^{-1} \mathrm{~d}^{-1}$ & - \\
\hline$k_{\operatorname{Min}}$ & Oxygen consumption rate & 10 & $\mathrm{~d}^{-1}$ & - \\
\hline$k_{\mathrm{OSR}}$ & Sulfate consumption rate & 0.0 & $d^{-1}$ & $*$ \\
\hline
\end{tabular}

(Boudreau, 1997; Berner, 1980) describes their concentrations as a function of time $(t)$, sediment depth $(z)$ and radius $(r)$

$$
\frac{\partial \phi C}{\partial t}=\frac{\partial}{\partial z}\left[\phi D^{*} \frac{\partial C}{\partial z}-\phi u C\right]+\frac{1}{r} \frac{\partial}{\partial r}\left[r \phi D^{*} \frac{\partial C}{\partial r}\right]+\phi \sum \text { Reac. }
$$

In this equation, $\phi$ is the sediment porosity (assumed constant), $u$ is the fluid flow velocity towards the sediment-water interface, $D^{*}$ is the mixing (diffusion) coefficient of the respective species in the worm $\left(D_{\mathrm{w}}\right)$ and in the sediment $\left(D_{\mathrm{s}}\right)$, and $\sum$ Reac is the sum of the production and consumption processes affecting each constituent.

In the tubeworm's body, very high mixing rates $\left(D_{\mathrm{w}}=\right.$ $\left.1 \times 10^{5} \mathrm{~cm}^{2} \mathrm{~d}^{-1}\right)$ are imposed, which to a large extent homogenise it (Table 1). In the sediment, the diffusion coefficient $\left(D_{\mathrm{s}}\right)$ is calculated from the molecular diffusion coefficient $(D)$, corrected for tortuosity (Boudreau, 1997) using the formula: $D_{\mathrm{s}}=\frac{D}{1-\log \left(\phi^{2}\right)}$. The molecular diffusion coefficient at the in situ temperature of $4^{\circ} \mathrm{C}$ was calculated using functions from the package marelac (Soetaert et al., 2012), available from the open source software R ( R Development Core Team, 2012).

The biogeochemical reactions that are considered are the anaerobic oxidation of methane (AOM), the re-oxidation of hydrogen sulfide (HSox), the sulfate reduction linked to or- ganic matter (OM) mineralisation (organoclastic sulfate reduction, OSR), and an oxygen consumption term other than sulfide oxidation (i.e. relating to OM mineralisation, Min) (Table 2). The latter two processes are necessary to make amends for the absence of regular diagenetic reactions that are associated with OM mineralisation. As we do not explicitly model nitrate, manganese- or iron oxides, which would be consumed before sulfate, we assume that the OSR occurs in the zone below the worm. For all reactions we use the simplest model formulation possible, i.e. oxygen consumption and organoclastic sulfate reduction is represented first order with respect to the oxygen and sulfate concentration, respectively, while AOM and HSox are represented by bimolecular rate kinetics (Table 2 ).

The solution of the 2-D partial differential Eq. (2) requires specification of boundary conditions at the upper and lower boundary (z-direction), and at the upstream and downstream edges in the horizontal (r-direction):

$\left.\frac{\partial C}{\partial r}\right|_{r=0}=0 ;\left.\quad \frac{\partial C}{\partial r}\right|_{r=R}=0$
$C_{z=0}=C_{0} ; \quad C_{z=\mathrm{L}}=C_{\mathrm{L}}$.

For the boundary conditions in the radial $(r)$ direction, zerogradient boundaries are assumed (Eq. 3). This imposes that 
the worm's effect on the sediment is restricted to its surrounding cylinder. The upper and lower boundaries (vertical, $\mathrm{z}$-direction) are defined as a concentration (Dirichlet boundary, Eq. 4); their values can be found in Table 1. The concentrations in the overlying bottom water $\left(C_{0}\right)$ were taken from the experimental data; for the lower boundary concentrations $\left(C_{\mathrm{L}}\right)$, they were manually tuned.

The model is implemented in the $\mathrm{R}$ package ReacTran (Soetaert and Meysman, 2012), available in the open source software R (R Development Core Team, 2012). This package provides functions to generate finite difference grids and discretises the partial differential equations (Eq. 2) together with their boundary conditions (Eqs. 3, 4) on these grids (Fig. 2c). In the radial direction, we considered 50 slices of unequal thickness. The slices in the worm body and in the $0.005 \mathrm{~cm}$ outside of the worm body were $0.001 \mathrm{~cm}$ thick, i.e. there were 5 cylinder slices in the worm body, and 5 equally thin slices immediately outside of the worm body. The other 40 cylindrical slices were about ten times as thick. The vertical extent was subdivided into 200 equally-sized layers of $0.175 \mathrm{~cm}$ each. With 4 chemical species, the model thus comprises 40000 nonlinear equations.

The equations are solved to steady state by NewtonRaphson iteration, as implemented in the $\mathrm{R}$ package rootSolve (Soetaert and Herman, 2009). It takes about 30 seconds to find a solution on a personal computer (Intel(R) Core(TM) i7CPU M640 @ 2.80 Ghz, 8 GB of memory).

\section{Results and discussion}

A key feature of many seep organisms such as the frenulate worms is that they contain Hemoglobins that bind oxygen and sulfide from the environment for transport to the endosymbiotic bacteria (e.g. Arp et al., 1987; Terwilliger et al., 1987). In a preliminary version of the model, we added oxygen and sulfide bound to Hemoglobin, but as many of the essential parameters are not well known or lacking, we decided to further simplify the representation of the worm in the model. It appeared that the capacity to store oxygen and sulfide is mainly of importance in transient situations, e.g. when the worm migrates between the oxic and anoxic zones. For the steady-state situations that we present here, the results with and without Hemoglobin are similar (not shown).

\subsection{Biogeochemical profiles}

The measured concentration-depth profiles and corresponding model fits are represented in (Fig. 3a-d).

Three zones can be discerned in the MUC15 sediment. The upper $10 \mathrm{~cm}$ is well homogenised with concentrations very similar to the bottom water concentrations. The sulfate concentration is nearly constant in the upper $9 \mathrm{~cm}$ of the sediment (29500-29900 $\mathrm{mmol} \mathrm{m}^{-3}$ ), while the sulfide concentration in the pore waters at these depths is below
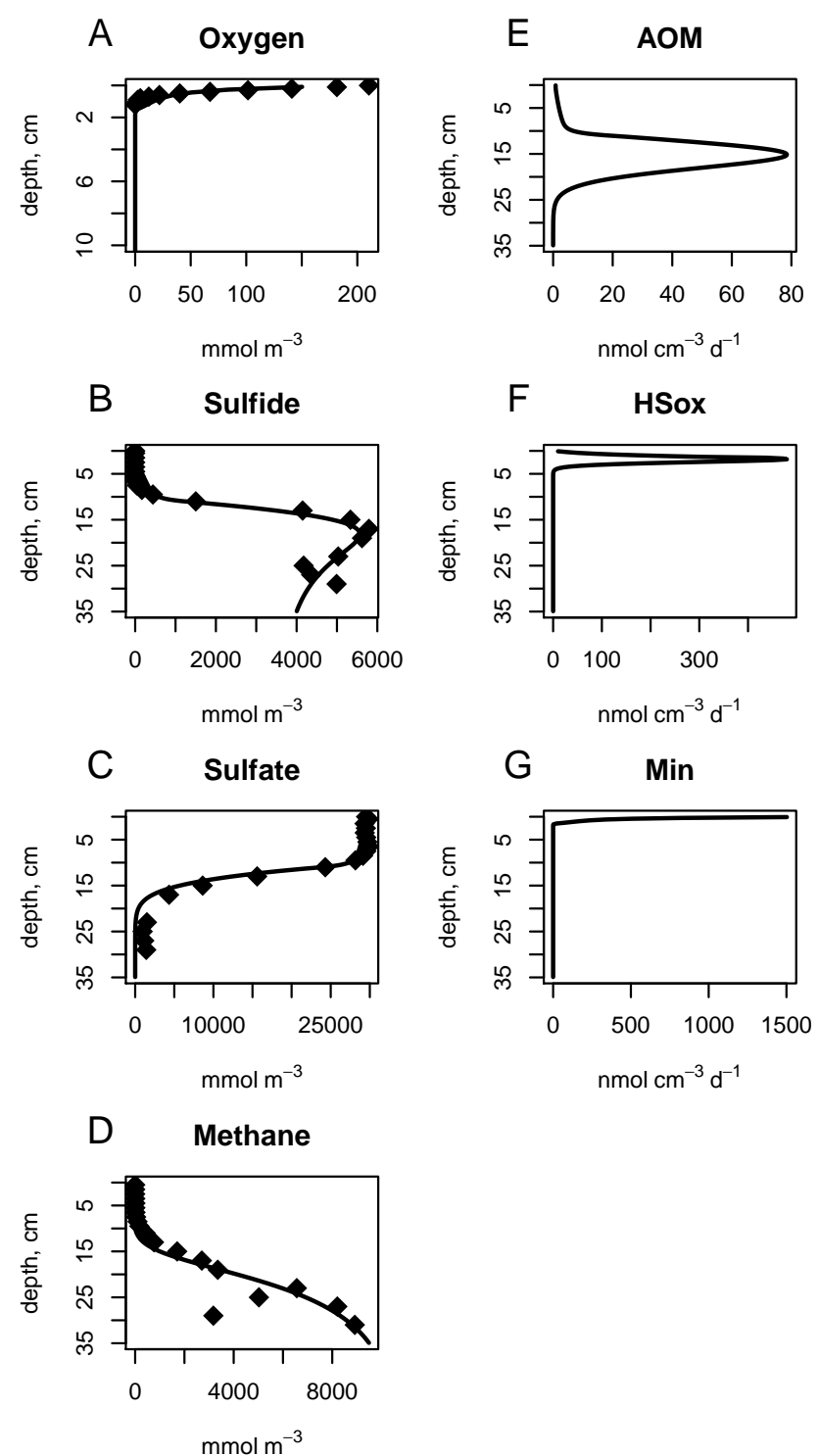

Fig. 3. (A-D) radially-averaged profiles of the concentrations of $\mathrm{O}_{2}, \mathrm{HS}^{-}, \mathrm{SO}_{4}^{2-}$, and $\mathrm{CH}_{4}$ and the corresponding model fits. The points are the data and the solid line is the model output. (E-G) Radially averaged profiles of the mean reaction rates. Units are in $\mathrm{nmol} \mathrm{S} \mathrm{cm}{ }^{-3} \mathrm{~d}^{-1}(\mathbf{E}-\mathbf{F})$ or in $\mathrm{nmol} \mathrm{O}_{2} \mathrm{~cm}^{-3} \mathrm{~d}^{-1}(\mathbf{G})$.

detection limit. Methane concentration is in the order of $1-10 \mathrm{mmol} \mathrm{m}^{-3}$ in the upper $7 \mathrm{~cm}$. Oxygen decreases from about $200 \mathrm{mmol} \mathrm{m}^{-3}$ to undetectable in the upper $2 \mathrm{~cm}$ of sediment.

There is a sharp chemocline below this well-mixed upper part, the sulfate-methane transition zone, extending from 10 to $20 \mathrm{~cm}$, where the AOM process takes place. The sulfide produced in this zone adds to the sulfide seeping from below and this causes a distinct maximum of around 5000$6000 \mathrm{mmol} \mathrm{m}^{-3}$, almost $2000 \mathrm{mmol} \mathrm{m}^{-3}$ above the deep sulfide concentration $\left(4000 \mathrm{mmol} \mathrm{m}^{-3}\right)$. 
Table 2. Model formulations and reactions; concentrations are denoted with brackets; $\mathrm{CH}_{2} \mathrm{O}$ represents organic matter, which is not explicitly described.

\begin{tabular}{lll}
\hline Description & Reaction & Rate expression \\
\hline Reactions $\mathrm{O}_{2}$ & & $\sum \mathrm{Reac}_{\mathrm{O}_{2}}=-R_{\mathrm{Min}}-2 R_{\mathrm{HSox}}$ \\
Reactions $\mathrm{SO}_{4}^{2-}$ & & $\sum \mathrm{Reac}_{\mathrm{SO}_{4}}{ }_{4}^{2-}=-R_{\mathrm{AOM}}+R_{\mathrm{HSox}}-R_{\mathrm{OSR}}$ \\
Reactions $\mathrm{HS}^{-}$ & & $\sum \mathrm{Reac}_{\mathrm{HS}}=+R_{\mathrm{AOM}}-R_{\mathrm{HSox}}+R_{\mathrm{OSR}}$ \\
$\begin{array}{l}\text { Reactions } \mathrm{CH}_{4} \\
\text { Mineralisation }\end{array}$ & $\mathrm{O}_{2}+\mathrm{CH}_{2} \mathrm{O} \rightarrow \mathrm{CO}_{2}+\mathrm{H}_{2} \mathrm{O}$ & $R_{\mathrm{Min}}=k_{\mathrm{Min}_{4}}\left[\mathrm{O}_{2}\right]$ \\
$\begin{array}{l}\text { Anaerobic oxidation } \\
\text { methane }\end{array}$ & $\mathrm{CH}_{4}+\mathrm{SO}_{4}^{2-} \rightarrow \mathrm{HCO}_{3}^{-}+\mathrm{HS}^{-}+\mathrm{H}_{2} \mathrm{O}$ & $R_{\mathrm{AOM}}=k_{\mathrm{AOM}}\left[\mathrm{SO}_{4}^{2-}\right]\left[\mathrm{CH}_{4}\right]$ \\
$\begin{array}{l}\text { Sulfide oxidation } \\
\text { Organoclastic }\end{array}$ & $\mathrm{HS}^{-}+2 \mathrm{O}_{2} \rightarrow \mathrm{SO}_{4}^{2-}+\mathrm{H}^{+}$ & $R_{\mathrm{HSox}}=k_{\mathrm{HSox}}\left[\mathrm{HS}^{-}\right]\left[\mathrm{O}_{2}\right]$ \\
sulfate reduction & $2 \mathrm{CH}_{2} \mathrm{O}+\mathrm{SO}_{4}^{2-} \rightarrow 2 \mathrm{HCO}_{3}^{-}+\mathrm{HS}^{-}+\mathrm{H}^{+}$ & $R_{\mathrm{OSR}}=k_{\mathrm{OSR}}\left[\mathrm{SO}_{4}^{2-}\right]$, for $z>\mathrm{Lw}$ \\
\hline
\end{tabular}

Finally, in the deep parts of the sediment $(>20 \mathrm{~cm})$ methane concentrations increase till about $9000 \mathrm{mmol} \mathrm{m}^{-3}$ at $35 \mathrm{~cm}$ depth, while sulfide concentrations decrease. Low concentrations of sulfate $\left(<1000 \mathrm{mmol} \mathrm{m}^{-3}\right)$ were measured here. Such a sulfate tailing appears to be common to seep environments; Dale et al. (2010) speculate that this is due to thermodynamic controls on the AOM community.

\subsection{Model results}

Before addressing the model results, we first discuss why we made certain choices and their implications.

The sensitivity of AOM to the model parameters is represented in Table 1. The AOM process is most sensitive to physical sediment characteristics such as sediment porosity, molecular diffusion coefficients of methane and sulfate, and the rate of upwelling, to the boundary conditions (bottom water concentration of sulfate and deep concentration of methane), as well as on the organoclastic sulfate reduction rate.

Both the organoclastic sulfate reduction and the anaerobic oxidation of methane can consume sulfate in the SMT zone (Table 2) and especially the OSR rate significantly affects AOM (Table 1). In the OSR the reduction of sulfate is coupled to the oxidation of organic molecules, whereas in the AOM process it is coupled to the oxidation of methane. We obtained the best fits to all profiles when putting the rate of OSR equal to 0 , thus minimising the total sulfate consumption rate (Table 1). Even in this case the sulfate reduction rate seems to be slightly overestimated as the model predicts sulfate depletion to occur at a too shallow depth (Fig. 3c). Consequently, methane is the only electron donor sustaining sulfate reduction in our model.

When AOM is the only sulfate consuming process, methane and sulfate are consumed in equal amounts (Eq. 1), and the fluxes of both constituents should balance (Malinverno and Pohlman, 2011). If we now assume that diffusion is the sole transport process, i.e. there is no upward fluid flow and methane does not migrate in gaseous form, then the profiles of sulfate and methane should be mirror images of one another, with any small discrepancies relating to the slightly different diffusion rates of both constituents (Table 1). Clearly this is not the case (Fig. 3c, d), as the methane profile below $20 \mathrm{~cm}$ is convex, and this is not mirrored by the sulfate profile. Two plausible explanations for such convex profiles are (1) there is production of methane in this zone (e.g., Methanogenesis, linked to OM degradation), and (2) the profiles are shaped by porewater flowing upward. It is very difficult to distinguish between both these causes based on the methane profile alone, so we let the fit to the sulfide profile decide between both options. The concave shape of sulfide at depths below $20 \mathrm{~cm}$ is easily reproduced by upwelling, whereas it would require an additional sink term in case upwelling was not included. Good fits were obtained with an upward fluid flow of $20 \mathrm{~cm} \mathrm{yr}^{-1}$ (Table 1).

It should be noted that the choice of upwelling may cause overestimation of the methane fluxes in the sediment as upward porewater flow significantly increases constituent fluxes (e.g. Regnier et al., 2011).

Overall the model satisfactorily describes the radially averaged concentration profiles, although there is a tendency to slightly overestimate the oxygen and sulfide concentrations in the upper $10 \mathrm{~cm}$ (Fig. 3a, b). Also, both the methane and sulfate concentrations are slightly lower in the model compared to the data. For instance, the model has all sulfate exhausted below $20 \mathrm{~cm}$, whereas sulfate was still measurable there (Fig. 3c).

The AOM process mainly takes place in the sediment zone extending from $10-20 \mathrm{~cm}$ deep. The model inferred rates of AOM peak around $15 \mathrm{~cm}$ deep, where they are around $80 \mathrm{nmol} \mathrm{cm}^{-3} \mathrm{~d}^{-1}$ (Fig. 3e). In contrast, the sulfide oxidation mainly occurs in the worm body and is restricted to a depth where trace amounts of oxygen and sulfide are simultaneously present. When averaged horizontally, the intense sulfide oxidation, up to $500 \mathrm{nmol} \mathrm{cm}^{-3} \mathrm{~d}^{-1}$ occurs in a narrow zone in the upper $5 \mathrm{~cm}$ of the sediment (Fig. 3f). 
Note that this sharp peak and even its position may be an artefact of the modelling, since it is possible to smear the thioautotrophic metabolism over a larger length of the body if Hemoglobin is included in the model (not shown). Finally, the oxygen consumption not related to sulfide oxidation declines rapidly from more than $1500 \mathrm{nmol} \mathrm{cm}^{-3} \mathrm{~d}^{-1}$ near the surface to virtually 0 at $2 \mathrm{~cm}$ (Fig. $3 \mathrm{~g}$ ).

\subsection{Biogeochemical budgets}

In Fig. 4 we present vertically and radially integrated budgets of the modeled constituents, where we make the distinction between processes occurring inside and outside of the worm.

Sulfide enters the sediment from the lower boundary at a rate of $128 \mathrm{nmol} \mathrm{cm}^{-2} \mathrm{~d}^{-1}$, while about three times as much $\left(374 \mathrm{nmol} \mathrm{cm}^{-2} \mathrm{~d}^{-1}\right)$ is produced by the AOM process (Fig. 4a). The majority of sulfide is consumed in the system, with about $71 \%$ of the sulfide reoxidation taking place in the worm. Assuming a worm mass density of $1 \mathrm{~g} \mathrm{~cm}^{-3}$ then the sulfide uptake of $351 \mathrm{nmol} \mathrm{cm}^{-2} \mathrm{~d}^{-1}$ is equivalent to a massspecific rate of $232 \mu \mathrm{mol} \mathrm{g}^{-1} \mathrm{~d}^{-1}$, which is about twice the measured sulfide uptake rates for Siboglinum fiordicum (92$93 \mu \mathrm{mol} \mathrm{g}{ }^{-1} \mathrm{~d}^{-1}$ ) (Southward et al., 1986), or for Lamellibrachia cf. luymesi $\left(70-113 \mu \mathrm{mol} \mathrm{g}^{-1} \mathrm{~d}^{-1}\right.$ ) (Freytag et al., 2001), and well within the ranges reported for several animals (Grieshaber and Völkel, 1998). The contribution of the worm's endosymbionts to total sulfide oxidation (71\%) is very high if we realise that, in the upper $11 \mathrm{~cm}$, where the model worm is living, only about $1 \%$ of the total volume is comprised by the body of the worm. Note however that the sulfide oxidation rates using oxygen in the sediment are probably overestimates, as sulfide oxidation using alternative electron acceptors (e.g. nitrate), or sulfide precipitation as $\mathrm{FeS}$ are not included in the model.

A significant part of sulfide oxidation takes place in the sediment surrounding the worm $\left(145 \mathrm{nmol} \mathrm{cm}^{-2} \mathrm{~d}^{-1}, 29 \%\right)$ where it is mainly fuelled by sulfide and oxygen leaking from the worm. The leakage and the partitioning of sulfide reoxidation between the worm and the sediment is however not well constrained by the data; it is a consequence of the permeability that we ascribed to the frenulate's body and tube and that causes diffusion of these constituents from the organism towards the sediment. Note that Dando et al. (2008) put forward a different strategy for HSox oxidation by seep organisms, suggesting that in environments with low ambient sulfide levels seep organisms could mine for insoluble sulfides. They argue that $\mathrm{O}_{2}$ from the organism is diffusing across the body wall and the tube into the sediment resulting in the oxidation of insoluble sulfides releasing thiosulfate and sulfide which in turn can be used by the organism. Whether these processes are important in CAMV sediments is not known.

The sulfide reoxidation produces sulfate, mainly in the worm's body ( $\left.351 \mathrm{nmol} \mathrm{cm}^{-2} \mathrm{~d}^{-1}\right)$, and this sulfate leaks out of the worm to the surrounding sediment (Fig. 4b). Surpris- ingly, there is a large influx of sulfate from the overlying water towards the worm $\left(916 \mathrm{nmol} \mathrm{cm}^{-2} \mathrm{~d}^{-1}\right)$, which adds to the sulfate that is produced by sulfide oxidation (Fig. 4b). In contrast, sulfate escapes to the water column from the sediment surrounding the worm body $\left(1038 \mathrm{nmol} \mathrm{cm}^{-2} \mathrm{~d}^{-1}\right)$. This apparent contradiction can be explained as follows. Both in the worm and in the surrounding sediment, there is a deficit of sulfate compared to the sulfate concentration in the overlying water. In the absence of upward advection of porewater, such deficit leads to an influx of sulfate across the sediment-water interface by mixing processes. In contrast, upward fluid flow will tend to expel sulfate out of the sediment. At the level of the sediment, the mixing by molecular diffusion is not efficient enough to counteract the loss by upwelling, while the vigorous mixing inside of the worm is able to do so. The net effect of these sedimentwater exchanges is that the sediment acts as a source of sulfate (Fig. 4b). Most of the sulfide seeping into the sediment $128 \mathrm{nmol} \mathrm{cm}^{-2} \mathrm{~d}^{-1}$ (Fig. 4a) is released to the water as sulfate $\left(122 \mathrm{nmol} \mathrm{cm}^{-2} \mathrm{~d}^{-1}\right.$, i.e. $95 \%$, Fig. 4 b), due to its efficient reoxidation with oxygen.

More than $98 \%$ of methane entering the sediment is oxidised by the AOM process $\left(374 \mathrm{nmol} \mathrm{cm}^{-2} \mathrm{~d}^{-1}\right.$, Fig. $4 \mathrm{c}$ ). It is noteworthy that very small amounts of methane are transported via the worm towards the water column $\left(6 \mathrm{nmol} \mathrm{cm}{ }^{-2} \mathrm{~d}^{-1}\right)$. The fact that this methane is not reoxidised in the worm body could be an artefact as the rate coefficients governing AOM dynamics $\left(k_{\mathrm{AOM}}\right.$, Table 1$)$ are representative for bulk sediment rates. But even if all methane entering the organism would be oxidised, this would amount to a mere $1.5 \%$ of the total AOM. Thus, although it has been suggested that certain Siboglinum species, including the species present at Captain Arutyunov may harbour methanotrophic symbionts (Schmaljohan, 1991; Dando et al., 1994; Sommer et al., 2009), there is little scope for methanotrophic activity in the body of our modeled worm. This is also clear from the position of the methane-sulfate transition zone which is well below the reach of the worm's tube (Fig. 3c, d).

About $78 \%$ of the oxygen that is consumed in the system is taken up by the frenulate worm $\left(1121 \mathrm{nmol} \mathrm{cm}^{-2} \mathrm{~d}^{-1}\right)$, where it is used for sulfide oxidation $\left(702 \mathrm{nmol} \mathrm{cm}^{-2} \mathrm{~d}^{-1}\right.$, $63 \%$, Fig. 4 d). The remaining fraction (37\%) of the worm's oxygen uptake leaks to the surrounding sediment where it is used for the oxic mineralisation $\left(435 \mathrm{nmol} \mathrm{cm}^{-2} \mathrm{~d}^{-1}\right)$ and sulfide oxidation $\left(290 \mathrm{nmol} \mathrm{cm}^{-2} \mathrm{~d}^{-1}\right)$.

Notwithstanding the small size of the worms, they are sites of intense biochemical activity and exchange with the overlying water and surrounding sediment (Fig. 4). For instance, total animal-sediment exchange rates for sulfate $\left(1267 \mathrm{nmol} \mathrm{cm}^{-2} \mathrm{~d}^{-1}\right)$ are 10 times larger than the net sediment-water exchange rate $\left(122 \mathrm{nmol} \mathrm{cm}^{-2} \mathrm{~d}^{-1}\right.$, Fig. $\left.4 \mathrm{~b}\right)$; sulfide uptake through the animal tube $\left(357 \mathrm{nmol} \mathrm{cm}^{-2} \mathrm{~d}^{-1}\right)$ is almost three times as large as the influx of sulfide with the seeping porewater $\left(128 \mathrm{nmol} \mathrm{cm}^{-2} \mathrm{~d}^{-1}\right.$, Fig. 4a). Oxygen is also vigorously exchanged between the worm and its 
A

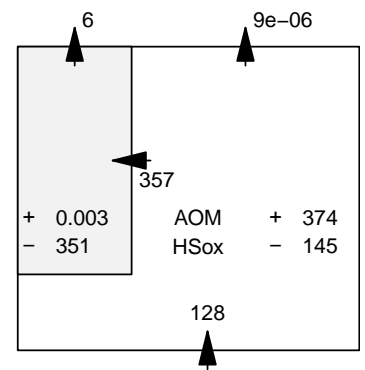

B

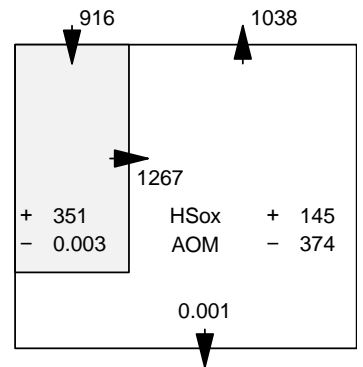

C

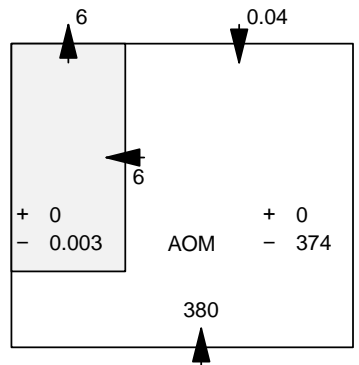

D

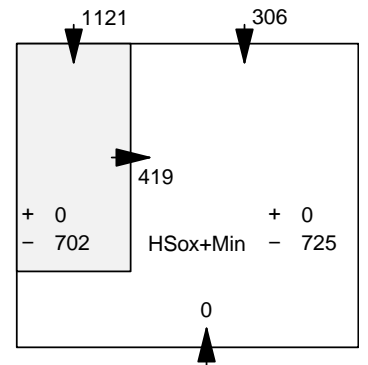

Fig. 4. Budgets of $\mathrm{HS}^{-}, \mathrm{SO}_{4}^{2-}, \mathrm{CH}_{4}$, and $\mathrm{O}_{2}$ in $\mathrm{nmol} \mathrm{cm}^{-2} \mathrm{~d}^{-1}$; the grey area is the worm; the upper interface is the sediment-water interface.

surrounding sediment. The oxygen leaking from the worm contributes for $58 \%$ to the oxygen consumed in the surrounding sediment (Fig. 4d). Such large leaking of oxygen out of the animal tube is corroborated by the observations that sediments immediately outside the tube are often visibly oxidised (Dando et al., 2008).

The large animal-sediment exchange rate is not surprising considering the fact that the total surface area of the worm $\left(0.315 \mathrm{~cm}^{2}\right)$ is only slightly smaller than that of the sediment-water interface $\left(0.35 \mathrm{~cm}^{2}\right)$. They are the reason that the presence of thin $(100 \mu \mathrm{m}$ diameter $)$ well-ventilated and permeable bodies in the sediment at the observed densities of 17500 individuals per $\mathrm{m}^{2}$ is sufficient to nearly completely homogenise the upper $10 \mathrm{~cm}$ of the sediment. These model results are consistent with observations that oxygen diffuses from polychaete tubes about one centimeter laterally into the sediment (Jørgensen and Revsbech, 1985).

\subsection{Siboglinum}

Before looking at the effect of animal density on sediment biogeochemistry it is instructive to calculate the porewater profiles and budgets in the absence of worms (Fig. 5a, Table $3 \mathrm{a}$ ). The no-worm scenario is representative for mud volcano sediments that are covered by mats of sulfideoxidising bacteria (de Beer et al., 2006). Without animal bioventilation, the upward fluid flow puts the SMT zone close to the sediment surface, in the vicinity of the oxygen-rich bottom water (Fig. 5a). The zone of AOM is thus near to the sediment-water interface but nonetheless the sediment shows only a small efflux of methane $\left(18 \mathrm{nmol} \mathrm{cm}^{-2} \mathrm{~d}^{-1}\right.$, only $5 \%$ of the influx), while sulfide does not leave the sediment (Table 3a). There is still complete recycling of sulfate, and about $30 \%$ of the sulfate produced by the sulfide oxidation now leaves the sediment.

In Fig. 5b, we represent the radially-averaged profiles of the various constituents when the worm is present at very low densities (1000 ind $\mathrm{m}^{-2}$ ). The integrated budget for this scenario is in Table $3 b$. Similarly as for the reference simulation (Fig. 3), we assumed the worm to be $11 \mathrm{~cm}$ long in
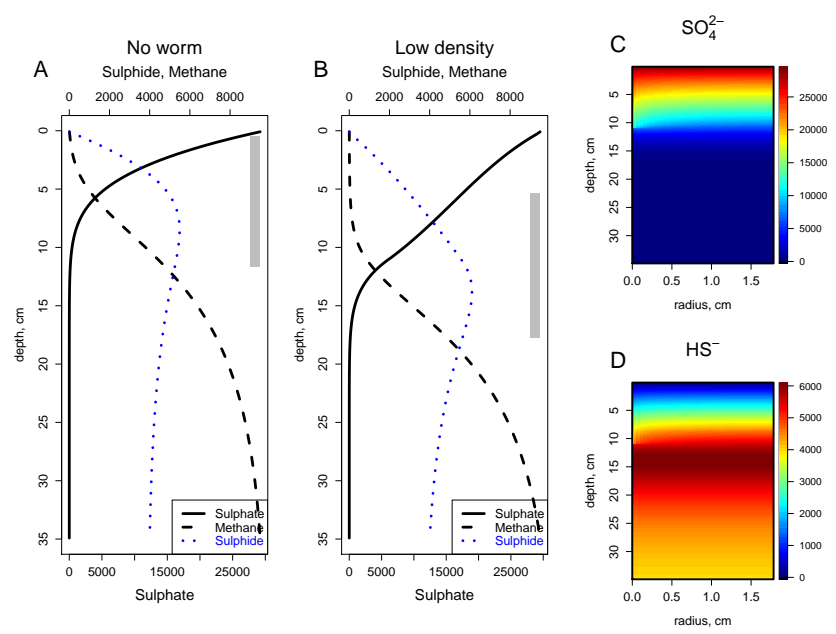

Fig. 5. (A) Radially-averaged concentration profiles in the absence of bio-irrigation; the grey box is the AOM zone. (B) Radially-averaged concentration profiles for a low worm density of 1000 ind $\mathrm{m}^{-2}$. (C) 2-D image plots of sulfate for the low worm density case. (D) 2-D image plots of sulfide for the low worm density case. Units are $\mathrm{mmol} \mathrm{m}^{-3}$.

the low worm density scenario. As is visible from the radially averaged profiles of sulfate and sulfide (Fig. 5b) and the 2-D images (Fig. 5c, d), in this case the worms are not able to fully push the methane-sulfate transition zone to the back end of their body. Rather, their posterior parts are surrounded by relatively large concentrations of sulfide due to seepage of sulfide-rich porewater (Fig. 5d). The sulfide enters the frenulate's body and due to the high mixing rates, a rather large efflux of sulfide to the water column ensues $\left(128 \mathrm{nmol} \mathrm{cm}^{-2} \mathrm{~d}^{-1}\right.$, Table $\left.3 \mathrm{~b}\right)$. It also follows that at these low densities and for worms of $11 \mathrm{~cm}$ in length, the sulfide concentration in the worm's body is elevated, so there may be no need for the worms to grow that long. Thus, the large sulfide effluxes, as in Table $3 \mathrm{~b}$, are probably not very realistic. 
Table 3. Biogeochemical budgets of oxygen, sulfate, sulfide and methane in the absence of a worm (A), and for low worm densities (B). Units of nmol cm $\mathrm{cm}^{-2} \mathrm{~d}^{-1}$.

\begin{tabular}{lrrrr}
\hline Species & $\begin{array}{r}\text { Bottom } \\
\text { influx }\end{array}$ & Production & Consumption & $\begin{array}{r}\text { Sediment- } \\
\text { water } \\
\text { efflux }\end{array}$ \\
\hline (A) No worm & & & & \\
$\mathrm{O}_{2}$ & 0 & 0 & 950 & -950 \\
$\mathrm{SO}_{4}^{2-}$ & 0 & 470 & 332 & 138 \\
$\mathrm{HS}^{-}$ & 138 & 332 & 470 & 0 \\
$\mathrm{CH}_{4}$ & 350 & 0 & 332 & 18 \\
\hline$(\mathbf{B}) 1000$ ind m${ }^{-2}$ & & & & \\
$\mathrm{O}_{2}$ & 0 & 0 & 825 & -825 \\
$\mathrm{SO}_{4}^{2-}$ & 0 & 359 & 356 & 3 \\
$\mathrm{HS}^{-}$ & 131 & 356 & 359 & 128 \\
$\mathrm{CH}_{4}$ & 364 & 0 & 356 & 8 \\
\hline
\end{tabular}

The effect of frenulate density and length on the sulfide oxidation process is represented in (Fig. 6a, b). We ran the model with densities of 1000,17500 , and $1 \times 10^{5}$ individuals per $\mathrm{m}^{2}$, which amounts to a sediment radius $(R)$ of 1.8 , 0.43 and $0.18 \mathrm{~cm}$, respectively. Steady-state conditions were calculated for worms of lengths in between 0.25 and $15 \mathrm{~cm}$, at $0.25 \mathrm{~cm}$ intervals.

Figure 6 a plots the sulfide oxidation per unit biomass as a function of the worm length for these three abundances, while Fig. $6 \mathrm{~b}$ does the same for the relative contribution of the worm in the sulfide oxidation process. The shapes of the biomass-specific sulfide oxidation rates as a function of length are similar for tubeworms living at different densities. At very low frenulate densities or for very short organisms $(<1 \mathrm{~cm})$, the sulfide oxidation rates per unit biomass are very close to zero, as the worms are not able to push the AOM zone deep enough for the sulfide to escape oxidation by surface-dwelling bacteria. As the worm length increases, it takes a larger share in sulfide oxidation (Fig. 6b) and so its biomass-specific sulfide oxidation rate increases (Fig. 6a). A maximum yield is reached at lengths of about 2.5, 3.25 and $8 \mathrm{~cm}$ at densities of 1000,17500 and $1 \times 10^{5}$ individuals $\mathrm{m}^{-2}$, respectively. However, even at their optimal length some 71,33 and $52 \%$ of the thioautotrophic activity is performed by free-living bacteria in the low, medium and high density scenario, respectively (Fig. 6b). As the worm grows further in length, e.g. in an attempt to keep up with or outcompete its neighbours in reaching the sulfide-rich layer, the same total HSox rate has to sustain a larger biomass and the yield decreases (Fig. 6a).

Not surprisingly, the amount of $\mathrm{HS}^{-}$oxidised per worm is highest for the communities at the lowest densities (Fig. 6a). Maximal rates were 0.04, 0.64 and $3.2 \mathrm{mmol} \mathrm{gWW}^{-1} \mathrm{~d}^{-1}$ at the highest, intermediate and lowest densities. The higher rates with lower densities is simply because worms living
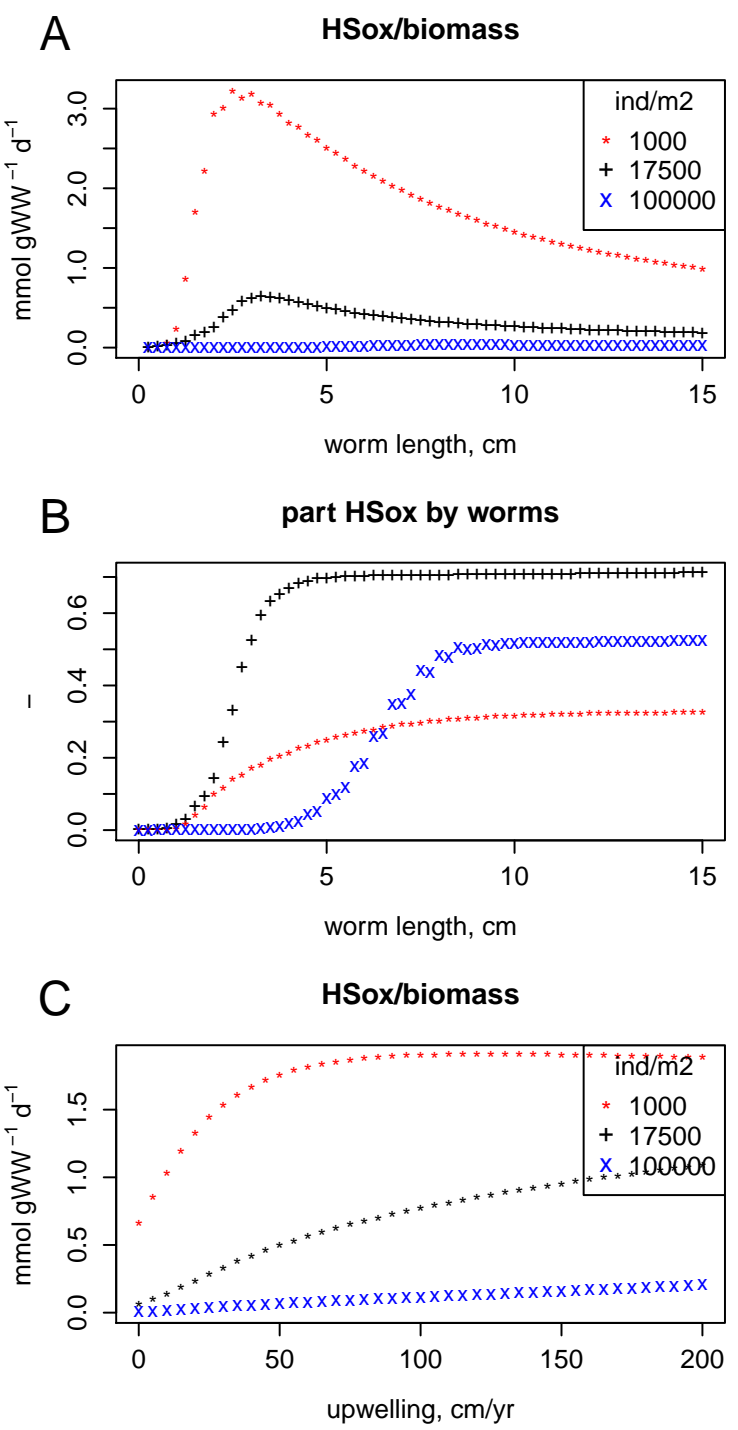

Fig. 6. (A) Biomass-specific sulfide oxidation rates, as a function of worm length for three different worm densities (1000, 17500 , $100000 \mathrm{ind} \mathrm{m}^{-2}$ ) and for an upwelling rate $=20 \mathrm{~cm} \mathrm{yr}^{-1}$. (B) Part of sulfide oxidation performed by the Siboglinid as a function of worm length. (C) Biomass-specific sulfide oxidation rates as a function of upwelling rate, for a worm of $11 \mathrm{~cm}$ long.

at lower densities have the potential to drain the sulfide produced by AOM from a much larger surface area. However, the more distantly the animals are spaced, the less influence they exert on the surrounding sediment. In the sediments in between organisms, the AOM will be pushed closer to the sediment water interface at lower densities (e.g., Fig. 5b) and this will cause more of the sulfide to be oxidised by free-living bacteria. This is clear when comparing the relative share between the communities at lowest and intermediate densities. If the relative share of the worm in the sulfide oxidation would remain the same, then animals living at densities equal to $1000 \mathrm{ind} \mathrm{m}^{-2}$ should reoxidise 22 
times more sulfide than animals living at densities equal to $17500 \mathrm{ind} \mathrm{m}^{-2}$, as this is the relative proportion of the surface areas from which the animal can harvest the sulfide. In reality, the difference is only 5 times: in the low density case more sulfide is oxidised by free-living bacteria as the worms are too distantly spaced.

At too high densities, not only have the worms access to lower amounts of sulfide, but also their share in oxidising sulfide is reduced (Fig. 6b). This can be explained as follows. The oxygen leaking out of the worm's body form a halo around the worm's tubes. If too closely packed, then the organisms halos will merge and push oxygen downward, bringing sulfide and oxygen closer together. This creates an environment more suitable for thiotrophic bacteria living in the sediment. Consequently, at higher densities, longer worms are necessary to prevent free-living bacteria to harvest the energy from the sulfide.

Finally, in Fig. 6c is depicted the biomass-specific sulfide oxidation rate as a function of upwelling intensity. With increasing upwelling, AOM increases, and hence also the sulfide oxidation rate per unit of biomass.

\section{Conclusions}

The activity of the small tubeworm Siboglinum sp., a dominant faunal inhabitant of the seep sediments at the Captain Arutyunov mud volcano, strongly modifies the biogeochemical conditions of the sediment it inhabits. It wins the competition with sediment-inhabiting bacteria for the thioautotrophic energy by bio-ventilating the upper layer of the sediment, thus separating the zones where sulfide and oxygen occur. For a specific frenulate density and upwelling rate there is an optimal length of the worm at which it can harvest most of the thiotrophic energy. This optimal length increases with increasing density. Worms that are too short will not push the sulfide production zone deep enough such that a much larger share of sulfide oxidation will be performed by free-living bacteria. This suggests that once established, mats of thioautotrophic bacteria are a stable state at cold seeps, and the invasion of such a bacterial mat area by frenulates through recruitment of larvae may be more difficult than through migration of larger specimens.

Our findings are relevant for all seep habitats which comprise similar tubeworms occurring at high densities. Siboglinids, as studied here, are prominent members of many cold seep ecosystems such as in the Skagerrak (e.g., Dando et al., 1994) or the Hakon Mosby mud volcano (e.g., de Beer et al., 2006). We have shown that these organisms act as "geo-engineers" by depressing the sulfate-methane transition zone. This may potentially allow other eukaryotic heterotrophic infauna that are less tolerant to high pore water sulfide levels to colonise these sediments. Therefore, the Siboglinids may represent a key species that affects successional patterns at cold seep communities.
There are several interesting paths in which this model can be further applied. It has been observed that frenulates move slowly up- and downwards. The effects of these movements, or under which conditions this may be necessary, could be investigated using transient model simulations. This requires that Hemoglobins are included in the model. Another interesting venue is to invest how the animals affect the $\mathrm{pH}$ dynamics (e.g. by excreting sulfate trough their tube), and how this alters the sulfur chemistry of the surrounding sediments (Dando et al., 2008). The model might also be applied to benthic macrofauna species that stimulate the efflux of $\mathrm{N}_{2} \mathrm{O}$ or $\mathrm{CH}_{4}$ from aquatic sediments due to bacterial activities directly associated with their body (Stief et al., 2009).

Acknowledgements. Eve Southward was very helpful in providing input on the physiology of the Siboglinum worms. Two anonymous referees are thanked for their instructive comments. This work was performed in the frame of the European Commission's Framework Seven Project HERMIONE (EC NR 226354).

Edited by: A. Boetius

\section{References}

Aller, R.: Quantifying solute distributions in the bioturbated zone of marine-sediments by defining an average micro-environment, Geochim. Cosmochim. Ac., 44, 1955-1965, 1980.

Amend, J., Edwards, K., and Lyons, T., (Eds.): Sulfide oxidation in marine sediments: Geochemistry meets microbiology, Special paper 379, Geological Society of America, 205 pp. 2004.

Arp, A., Childress, J., and Vetter, R. D.: The sulphide-binding protein in the blood of the vestimentiferan tube-worm Riftia pachyptila, is the extracellular haemoglobin, J. Exp. Biol., 128, 139158, 1987.

Berner, R. A.: Early Diagenesis: A Theoretical Approach, Princeton Series in Geochemistry, Princeton University Press, Princeton, available at: http://books.google.nl/books?id=weRFglCVBkUC, 1980.

Boetius, A. and Suess, E.: Hydrate ridge: a natural laboratory for the study of microbial life fueled by methane from near-surface gas hydrates, Chem. Geol., 205, 291-310, doi:10.1016/j.chemgeo.2003.12.034, 2004.

Boetius, A., Ravenschlag, K., Schubert, C., Rickert, D., Widdel, F., Gieseke, A., Amann, R., Jørgensen, B., Witte, U., and Pfannkuche, O.: A marine microbial consortium apparently mediating anaerobic oxidation of methane, Nature, 407, 623-626, doi:10.1038/35036572, 2000.

Boudreau, B. P.: Diagenetic models and their implementation: modelling transport and reactions in aquatic sediments, Springer, Berlin, available at: http://books.google.nl/books?id= p1bwAAAAMAAJ, 1997.

Cavanaugh, C. M., McKiness, Z., Newton, I., and Stewart, F.: Prokaryotes, 1, 475-507, 2006.

Cardoso, R. B., Sierra-Alvarez, R., Rowlette, P., Flores, E.R., Gómez, J., Field J.A.: Sulfide oxidation under chemolithotrophic denitrifying conditions, Biotechnol. Bioeng., 95, 1148-1157, doi:10.1002/bit.21084, 2006. 
Cordes, E., Arthur, M., Shea, K., Arvidson, R., and Fisher, C.: Modeling the mutualistic interactions between tubeworms and microbial consortia, Plos Biol., 3, 497-506, 2005.

Dale, A., Sommer, S., Haeckel, M., Wallmann, K., Linke, P., Wegener, G., and Pfannkuche, O.: Pathways and regulation of carbon, sulfur and energy transfer in marine sediments overlying methane gas hydrates on the Opouawe Bank (New Zealand), Geochim. Cosmochim. Ac., 74, 5763-5784, 2010.

Dando, P., Bussmann, I., Niven, S., O'Hara, S., Schmaljohann, R., and Taylor, L.: A methane seep area in the Skagerrak, the habitat of the pogonophore Siboglinum poseidoni and the bivalve mollusc Thyasire sarsi, Mar. Ecol.-Prog. Ser., 107, 157-167, 1994.

Dando, P., Southward, A., Southward, E., Lamont, P., and Harvey, R.: Interactions between sediment chemistry and frenulate pogonophores (Annelida) in the North-East Atlantic, Deep-Sea Res. Pt. I, 55, 966-996, 2008.

de Beer, D., Sauter, E., Niemann, H., Kaul, N., Witte, U., Schluter, M., and Boetius, A.: In situ fluxes and zonation of microbial activity in surface sediments of the Hakon Mosby Mud Volcano, Limnol. Oceanogr., 51, 1315-1331, 2006.

Fischer, D., Sahling, H., Nöthen, K., Bohrmann, G., Zabel, M., and Kasten, S.: Interaction between hydrocarbon seepage, chemosynthetic communities, and bottom water redox at cold seeps of the Makran accretionary prism: insights from habitatspecific pore water sampling and modeling, Biogeosciences, 9, 2013-2031, doi:10.5194/bg-9-2013-2012, 2012.

Freytag, J., Girguis, P., Bergquist, D., Andras, J., Childress, J., and Fisher, C.: A paradox resolved: sulfide acquisition by roots of seep tubeworms sustains net chemoautotrophy, P. Natl. Acad. Sci., 98, 13408-13413, 2001.

Grieshaber, M. and Völkel, S.: Animal adaptations for tolerance and exploitation of poisonous sulfide, Ann. Rev. Physiol., 60, 33-53, 1998.

Grigg, N., Boudreau, B., Webster, I., and Ford, P.: The nonlocal model of porewater irrigation: limits to its equivalence with a cylinder diffusion model, J. Mar. Res., 63, 437-455, 2005.

Haese, R. R., Meile, C., Van Cappellen, P., and De Lange, G. J.: Carbon geochemistry of cold seeps: methane fluxes and transformation in sediments from Kazan mud volcano, Eastern Mediterranean Sea, Earth Planet. Sci. Lett., 212, 361-375, doi:10.1016/S0012-821X(03)00226-7, 2003.

Hensen, C., Nuzzo, M., Hornibrook, E., Pinheiro, L., Bock, B., Magalhaes, V., and Bruckmann, W.: Sources of mud volcano fluids in the Gulf of Cadiz - indications for hydrothermal imprint, Geochim. Cosmochim. Ac., 71, 1232-1248, 2007.

Hentschel, U., Cary, S. C., and Felbeck, H.: Nitrate respiration in chemoautotrophic symbionts of the bivalve Lucinoma aequizonata, Mar. Ecol.-Prog. Ser., 94, 35-41, 1993.

Hilario, A., Johnson, S., Cunha, M., and Vrijenhoek, R.: High diversity of frenulates (Polychaeta:Siboglinidae) in the Gulf of Cadiz mud volcanoes: a DNA taxonomy analysis, Deep-Sea Res. Pt. I, 57, 143-150, 2010.

Jørgensen, B. and Nelson, D. C.: Sulfide oxidation in marine sediments: Geochemistry meets microbiology, in Sulfur Biogeochemistry - Past and present, edited by: Amend, J. P., Edwards, K. J., and Lyons, T. W., Geological Society of America Special Paper, 379, 63-81, 2004.

Jørgensen, B. and Revsbech, N.: Diffusive boundary layers and the oxygen uptake of sediments and detritus, Limnol. Oceanogr., 30,
111-122, 1985.

Judd, A. G. and Hovland, M.: Seabed Fluid Flow, The Impact on Geology, Biology and the Marine Environment, Cambridge University Press, Cambridge, 2007.

Kruger, M., Treude, T., Wolters, H., Nauhaus, K., and Boetius, A.: Microbial methane turnover in different marine habitats, Palaeogeogr. Palaeocl., 227, 6-17, doi:10.1016/j.palaeo.2005.04.031, 2005.

Levin, L. A.: Ecology of cold seep sediments: interactions of fauna with flow, chemistry and microbes, Oceanogr. Mar. Biol., 43, 146, 2005.

Little, C. and Gupta, B. L.: Studies on pogonophora, III. Uptake of nutrients, J. Exp. Biol., 51, 759-773, 1969.

Luff, R., Wallmann, K., and Aloisi, G.: Numerical modeling of carbonate crust formation at cold vent sites: significance for fluid and methane budgets and chemosynthetic biological communities, Earth Planet. Sci. Lett., 221, 337-353, 2004.

Malinverno, A. and Pohlman, J. W.: Modeling sulfate reduction in methane hydrate-bearing continental margin sediments: does a sulfate-methane transition require anaerobic oxidation of methane?, Geochem. Geophys. Geosy., 12, Q07006, doi:10.1029/2011GC003501, 2011.

Martens, C. S. and Berner, R. A.: Interstitial water chemistry of anoxic Long Island Sound sediments, Limnol. Oceanogr., 22, 10-25, 1977.

Nielsen, L.P., Risgaard-Petersen, N., Fossing, H., Christensen, P. B. and Sayami, M.: Electric currents couple spatially separated biogeochemical processes in marine sediment, Nature, 463, 10711074, 2010.

Niemann, H., Duarte, J., Hensen, J., Omoregie, E., Magalhaes, V. H., Elvert, M., Pinheiro, L. M., Kopf, A., and Boetius, A.: Microbial methane turnover at mud volcanoes of the Gulf of Cadiz, Geochim. Cosmochim. Ac., 70, 5336-5355, 2006.

R Development Core Team: R: A Language and Environment for Statistical Computing, R Foundation for Statistical Computing, Vienna, Austria, available at: http://www.R-project.org, ISBN 3900051-07-0, 2012.

Reeburgh, W. S.: Soft spots in the global methane budget, Kluwer Academic Publishers, Dordrecht, 1996.

Regnier, P., Dale, A. W., Arndt, S., LaRowe, D. E., Mogollon, J., and Van Cappellen, P.: Quantitative analysis of anaerobic oxidation of methane (AOM) in marine sediments: a modeling perspective, Earth-Sci. Rev., 106, 105-130, doi:10.1016/j.earscirev.2011.01.002, 2011.

Schmaljohan, R.: Oxidation of various potential-energy sources by the methanotrophic endosymbionts of Siboglinum poseidoni (Pogonophora), Mar. Ecol.-Prog. Ser., 76, 143-148, 1991.

Sibuet, M. and Olu, K.: Biogeography, biodiversity and fluid dependence of deep-sea cold-seep communities at active and passive margins, Deep-Sea Res. Pt. II, 45, 517-567, 1998.

Soetaert, K. and Herman, P. M. J.: A Practical Guide to Ecological Modelling, Using R as a Simulation Platform, Springer, Berlin, ISBN 978-1-4020-8623-6, 2009.

Soetaert, K. and Meysman, F.: Reactive transport in aquatic ecosystems: Rapid model prototyping in the open source software R, Environ. Model. Softw., 32, 49-60, 2012.

Soetaert, K., Petzoldt, T., and Meysman, F.: marelac: Tools for Aquatic Sciences, available at: http://R-Forge.R-project.org/ 
projects/marelac/2012, R package version 2.1.1, 2012.

Sommer, S., Tuerk, M., Kriwanek, S., and Pfannkuche, O.: Gas exchange system for extended in situ benthic chamber flux measurements under controlled oxygen conditions: First application - sea bed methane emission measurements at Captain Arutyunov mud volcano, Limnol. Oceanogr.-Meth., 6, 23-33, 2008.

Sommer, S., Linke, P., Pfannkuche, O., Schleicher, T., Schneider, V., Deimling, J., Reitz, A., Haeckel, M., Fløgel, S., and Hensen, C.: Seabed methane emissions and the habitat of frenulate tubeworms on the Captain Arutyunov mud volcano (Gulf of Cadiz), Mar. Ecol.-Prog. Ser., 382, 69-86, 2009.

Southward, A. and Southward, E.: Notes on the biology of some pogonophores, J. Mar. Biol. Assoc. UK, 43, 57-64, 1963.

Southward, A., Southward, E. C., Brattegard, T., and Bakke, T.: Further experiments on the value of dissolved organic matter as food for Siboglinum fiordicum (Pogonophora), J. Mar. Biol. Assoc. UK, 59, 133-148, 1979.
Southward, A., Southward, E., Dando, P., Barrett, R., and Ling, R.: Chemoautotrophic function of bacterial symbionts in small Pogonophora, J. Mar. Biol. Assoc. UK, 66, 415-437, 1986.

Stief, P., Poulsen, M., Nielsen L. P., Brix, H., and Schram, A: Nitrous oxide emission by aquatic macrofauna, P. Natl. Acad. Sci., 106, 4296-4300, 2009.

Terwilliger, R., Terwilliger, N., Hughes, G., Southward, A., and Southward, E.: Studies on the haemoglobin of the small Pogonophora, J. Mar. Biol. Assoc. UK, 67, 219-234, 1987.

Valentine, D. L.: Biogeochemistry and microbial ecology of methane oxidation in anoxic environments: a review, Anton. Leeuw., 81, 271-282, 2002.

Wallmann, K., Linke, P., Suess, E., Bohrmann, G., Sahling, H., Schluter, M., Dahlmann, A., Lammers, S., Greinert, J., and von Mirbach, N.: Quantifying fluid flow, solute mixing, and biogeochemical turnover at cold vents of the eastern Aleutian subduction zone, Geochim. Cosmochim. Ac., 61, 5209-5219, doi:10.1016/S0016-7037(97)00306-2, 1997. 